\title{
EFFECT OF DIFFERENT HORMONAL TREATMENTS AS THERAPEUTIC PROCEDURE ON REPEAT BREEDER BUFFALO HEIFERS
}

\author{
A.E. Abdel-Khalek ${ }^{1}$, M.A. El- Harairy ${ }^{1}$, S.A. Darwish ${ }^{2}$, H.K. Zaghloul ${ }^{3}$ and M.A. Abo Farw ${ }^{2}$ \\ 1- Animal Production Department, Faculty of Agriculture, Mansoura University, Egypt, 2- Animal \\ Production Research Institute, Agricultural Research Center, Giza, Egypt, 3- Higher Institute For \\ Agricultural Co-Operation, Shoubra, Egypt
}

\section{SUMMARY}

Total of 30 Egyptian buffalo heifers (20-25 months and 340-360 kg) failed to conceive after 3 services (repeat breeder heifers) were exposed to three hormonal protocols after exhibiting the $4^{\text {th }}$ estrous cycle. In the $1^{\text {st }}$ protocol, heifers $(n=10)$ were injected with $G n R H$ on day of estrus and service. In the $2^{\text {nd }}$ protocol, heifers $(n=10)$ were injected with GnRH on day of estrus ( 0 day), followed by $P G F_{2} \alpha$ on day 7. Heifers displaying estrus within $48 \mathrm{hr}$ of $P G F_{2} \alpha$ injection were served, while those did not show estrus within 48 here injected with a second dose of GnRH on day 9 and served on day 10. In the $3^{r d}$ protocol, heifers $(n=10)$ were injected with $1^{s t} P G F_{2} \alpha$ injection starting on day 6 after exhibiting the $4^{\text {th }}$ estrous cycle. Animals exhibiting estrus within $72 \mathrm{hr}$ after $1^{\text {st }} \mathrm{PGF}_{2} \alpha$ injection were served, while those did not exhibit estrus were re-injected after 11 days of the $1^{\text {st }}$ injection with $2^{\text {nd }}$ $\mathrm{PGF}_{2} \mathrm{\alpha}$ and served 24-48 hr later. Pregnancy was diagnosed by ultrascan after 35.d of service. At service, diameter of the largest follicles was recorded for the $1^{\text {st }}$ and $2^{\text {nd }}$ protocols, while diameter of corpus luteum (CL) was recorded for the $3^{\text {rd }}$ protocol using ultrascan. Blood samples were collected pre- and post- hormonal injections of each protocol for determination of progesterone (P4) concentrations in blood serum of all animals. Results showed that conception rate $(C R)$ in the $1^{\text {st }}$ protocol was $80 \%$ and mean diameter of the largest follicle was 13.25 and $9.10 \mathrm{~mm}$ in conceived and non-conceived heifers, respectively. Concentration of P4 was lower pre-treatment and at service in conceived heifers (3.063 and $0.182 \mathrm{ng} / \mathrm{ml})$ than in non-conceived heifers $(5.828$ and $0.296 \mathrm{ng} / \mathrm{ml}$ ), while, an opposite trend was observed post-treatment (5.802 and $3.541 \mathrm{ng} / \mathrm{ml}$ ), respectively. In the $2^{\text {nd }}$ protocol, after $\mathrm{PGF}_{2} \alpha$ injection, estrus rate was 50\% (within 48 h) and CR was $80 \%$ based on inseminated animals. Mean diameter of the largest follicle was 8.3 and $7.0 \mathrm{~mm}$ in conceived and nonconceived heifers, respectively. After the $2^{\text {nd }}$ GnRH and blind service, CR was $60 \%$ and mean diameter of largest follicle was 8.9 and $4.7 \mathrm{~mm}$ in conceived and non-conceived heifers, respectively. The final CR after GnRH-PGF $F_{2} \alpha-G n R$ was $70 \%$. The $1^{\text {st }}$ GnRH injection increased P4 concentration in all treated heifers, while $P G F_{2} \alpha$ injection reduced $P 4$ level to 0.433 and $1.420 \mathrm{ng} / \mathrm{ml}$ in conceived and non-conceived heifers, respectively. In the $3^{\text {rd }}$ protocol, estrus rate was $50 \%$ within $72 \mathrm{~h}$ after the $1^{\text {st }}$ $P G F_{2} \alpha$ injection and $C R$ was $80 \%$. Mean diameter of $C L$ at service was $11.3 \mathrm{~mm}$. All heifers (100\%) injected with $2^{\text {nd }} \mathrm{PGF}_{2} \alpha$ exhibited estrus (within 48-72 h), served and conceived. Mean CL diameter was $10.6 \mathrm{~mm}$. For the whole $3^{\text {rd }}$ protocol (after both $P G F_{2} \alpha$ injections), $C R$ was $90 \%$ and mean diameter of CL was $10.9 \mathrm{~mm}$. The $3^{\text {rd }}$ protocol had the cheapest cost and the highest conception, followed by the $1^{\text {st }}$ protocol, while the $2^{\text {nd }}$ protocol showed the highest cost.

\section{Keywords: Buffalo heifers, repeat breeder, hormonal treatment.}

\section{INTRODUCTION}

Reproductive efficiency is the core of dairy farms profitability (Nebel and Jobst, 1998). Maximum economic return could be achieved when females conceive early with fewer services (less than three inseminations). Females those don't get pregnant by the third service are referred as 'repeat-breeders'. Repeat breeding, which occurs in $10-25 \%$ for cows, is one of the major gynecological problems affecting reproductive efficiency and profitability of dairy farms (Bartlett et al., 1986).

Follicular dynamics and pituitary-ovarian axis are the main reasons for repeat-breeding phenomenon (Båge et al., 1997). Within the six days post estrus, repeat breeders have lower progesterone concentrations relative to normal ones (Båge, 2002). To overcome this inconvenient phenomenon in dairy farms $\mathrm{GnRH}$ and prostaglandin F2 $\alpha$ (PGF2 $\alpha$ ) have been used in different combinations to improve the reproductive efficiency in lactating dairy cows (Yaniz et al., 2004) and Egyptian buffaloes (Hegazy, 2001).

Therefore, the aim of the current study is to test the more efficient hormonal protocols to improve reproductive performance of repeated breeder buffalo heifers.

\section{MATERIALS AND METHODS}

This study was carried out at Animal Production Experimental Station, Mehallet Moussa, Kafer El-sheikh Govemorate (located in the north of the Nile Delta), during the period from May to September 2008. 
Animals:

A total of 30 Egyptian buffalo heifers those failed to conceive after 3 services (repeat breeders) was used in this study. Heifers had 20-25 month old and body weight of 340-360 $\mathrm{kg}$. Animals were fed on concentrate feed mixture, maize silage, rice straw, and berseem (Trifolium alexandrinum) hay according to the systems adopted by Animal Production Research Institute (APRI). Fresh water was made available all times, since heifers were housed loose in semi-open sheds.

\section{Treatment protocols:}

In all treatments, heifers exhibiting the $4^{\text {th }}$ estrous cycle (failed to conceive after 3 services) were exposed to therapeutic treatments.

Heifers in the $1^{\text {st }}$ protocol $(n=10)$ were treated with intramuscularly injected at the time of service with a single dose of $5 \mathrm{ml}$ GnRH analogue (Receptal, Hoechst, Germany) containing $20 \mu \mathrm{g}$ Buserelin GnRH.

In the $2^{\text {nd }}$ protocol, heifers $(n=10)$ were i.m. injected with $5 \mathrm{ml} \mathrm{Receptal}$ at day of estrus (0 day), followed by i.m. injection on day 7 with $3 \mathrm{ml} \mathrm{PGF} 2 \alpha$ analogue (Synchromate, Bremer Pharma 27540 Bremerhaven, Germany) containing $0.750 \mu \mathrm{g}$ cloprostenol. Heifers those did not display estrus signs within $48 \mathrm{hr}$ after $\mathrm{PGF}_{2} \alpha$ were i.m. injected with a second dose of $5 \mathrm{ml}$ Receptal (day 9), followed by a natural mating 24 hr later (day 10).

In the $3^{\text {rd }}$ protocol, heifers were injected with i.m dose of $3 \mathrm{ml} \mathrm{PGF}_{2} \alpha$ analogue. Animals those exhibit heat symptoms within 72 hours after treatment were served naturally. Animals which did not exhibit estrous activity were re-treated after 11 days with a second dose of $3 \mathrm{ml}$ Synchromate and naturally mated 24-48 $\mathrm{h}$ after the $2^{\text {nd }}$ dose.

\section{Estrous detection, service and pregnancy diagnosis:}

Estrus was detected within 3 days post GnRH injection ( $1^{\text {st }}$ protocol), post- $\mathrm{PGF}_{2} \alpha$ injection $\left(2^{\text {nd }}\right.$ protocol) and post $1^{\text {st }}$ and $2^{\text {nd }}$ $\mathrm{PGF}_{2} \alpha$ injections ( $3^{\text {rd }}$ protocol) using a teaser buffalo bull for four times/day at 8 and 12 a.m. as well as 4 and 8 p.m. Heifers detected in heat were naturally inseminated with fertile buffalo bull.

Pregnancy diagnosis was carried out on day 35 post-insemination for animals non-returned to estrus after 24 days using ultrascan (Falco, Easote/Piemedical, Maastricht, 6-8 MH2 Linear array transducer, Alliance Medical Int.) and confirmed by rectal palpation on day 60 post-insemination. Also, ultrascan was used for estimation of the largest follicles following the insemination $\left(1^{\text {st }}\right.$ and $2^{\text {nd }}$ protocols) and for estimation of corpus luteum (CL) diameter on day of $1^{\text {st }}$ and $2^{\text {nd }}-\mathrm{PGF}_{2} \alpha$ in the $3^{\text {rd }}$ protocol.

\section{Blood sampling:}

At 8 a.m. before feeding, blood samples were collected from the jugular vein for progesterone (P4) determination. Blood samples were centrifuged for 15 minutes at 3000 r.p.m. for serum separation, which stored at $-20{ }^{\circ} \mathrm{C}$ till the $\mathrm{P} 4$ assay. Blood samples were collected from all animals in each protocol as follows: The $1^{\text {st }}$ protocol: $48 \mathrm{~h}$ pre-GnRH, service and $48 \mathrm{~h}$ post-GnRH. The $2^{\text {nd }}$ protocol: $24 \mathrm{hr}$ pre- and post $1^{\text {st }} \mathrm{GnRH}, 48 \mathrm{hr}$ post$\mathrm{PGF}_{2} \alpha$ and $24 \mathrm{~h}$ post-insemination. The $3^{\text {rd }}$ protocol: $24 \mathrm{hr}$ pre- and $48 \mathrm{hr}$ post- $1^{\text {st }} \mathrm{PGF}_{2} \alpha$, as well as $24 \mathrm{hr}$ pre- and $48 \mathrm{hr}$ post- $2^{\text {nd }} \mathrm{PGF}_{2} \alpha$. In all protocols, blood samples were taken on day 24 post-insemination.

\section{Progesterone (P4) assay:}

Direct radioimmunoassay technique (RIA) was performed for determination of $\mathrm{P} 4$ concentrations in blood serum samples using ready antibody coated tubes kit (Diagnosis Systems Laboratories, Texas, USA) according to the procedure outlined by the manufacturer.

According to the manufacture's information, the cross reaction of progesterone antibody (at $50 \%$ binding), was $100 \%$ with $\mathrm{P} 4$, while was $6.00,2.50,1.20,0.80,0.48$, and $0.10 \%$ with $5 \alpha$-pregnone-3, 20-dione 11Deoxycorticosterone, $17 \alpha$ Hydroxyprogesterone, 5 3 -pregnone-3, 20dione 11-Deoxycortisol, and 20 $\alpha$ Dihydroxyprogesterone, respectively and less than $0.1 \%$ with any of the other steroids.

The standard curve of $\mathrm{P} 4$ ranged from 0.0 to $60.0 \mathrm{ng} / \mathrm{ml}$. The sensitivity value was reported to be $0.12 \mathrm{ng} / \mathrm{ml}$. The intra and interassay coefficients of variation were $8.0 \%$ and 13.1 .

\section{Economic evaluation:}

Economic evaluation of each hormonal protocol was calculated as total cost based on price and number of injections for each treated animal, and then for 10 animals.

\section{Statistical Analysis:}

Results were statistically analyzed according to Snedecor and Cocharn (1982). Analysis of variance using one way design was used to compare P4 concentrations between conceived and non-conceived heifers. While, conception and estrus rate was tested using Chi-square analysis.

\section{RESULTS AND DISCUSSION}

\section{$I^{\text {st }}$ Protocol: "GnRH at estrus"}

Results (Tabl1 1 and figure 1) of this treatment revealed that conception rate $(\mathrm{CR})$ of treated heifers was $80 \%$ (8/10). Mean diameter 
of the largest follicles was wider in conceived heifers than in non-conceived heifers (13.25 vs. $9.10 \mathrm{~mm}$, Plate $1 \mathrm{~A}$ and B). Pregnancy in conceived heifers was proved by ultrasound examination (Plate $1 \mathrm{C}$ ) on day 35 postinsemination and confirmed on day 60 postinsemination by rectal palpation.

Similarly, Kaim et al. (2003) found that $\mathrm{GnRH}$ injection at estrus increased CR of cows from 41.3 to $55.5 \%$ across seasons compared to control. They reported that if $\mathrm{GnRH}$ treatment was given at estrus, failure or delay of ovulation might be prevented and CR might increase. Also, Nakao et al. (1984) mentioned that administering $\mathrm{GnRH}$ at estrus might prevent ovulation failure or reduce the variation in the interval to ovulation. These findings could be related to the fact that repeat breeder heifers have a smaller preovulatory $\mathrm{LH}$ surge than virgin heifers, therefore, an increase in the spontaneous surge that results from the administrating GnRH at estrus affects the CR favorably (Kaim et al., 2003). Also, in most other studies, GnRH administered at artificial insemination may induce a second $\mathrm{LH}$ peak and did not increase the spontaneous one (Ryan et al., 1994).

On the other hand, Stevenson, et al. (1988) suggested that GnRH-induced ovulation may provide greater synchrony between the time of insemination and the time of ovulation. In this respect, Stevenson et al. (1984) found that conception rates increased when cows were treated in the first 5 to 8 hours of estrus. Furthermore, Peters (2005) indicated the use of GnRH as a 'holding' injection on the day of insemination led to improve the chances of successful pregnancy, particularly in repeat breeder cows.

The present study indicated that pregnancy of treated animals was associated with wider diameter of the largest follicle. Ovulation of large follicle yields higher CR (Mussard et al., 2003). In this respect, Perry et al. (2005) reported induced ovulation of large follicles (11.3 $\mathrm{mm}$ in diameter). Also, Perry et al. (2007) found that heifers having ovulated follicles with diameter of 10.7-15.7 mm at time of artificial insemination were more likely to become pregnant than that ovulated a follicle with a more diameter.

In comparing $\mathrm{P} 4$ profile during the fourth estrous cycle pre-treatment and post-GnRH treatment in treated animals, it was found that P4 concentration was higher in non-conceived heifers than in conceived heifers at different sampling days of estrous cycle. However, the opposite situation was observed during posttreatment period (24 days post-service), which can indicate the incidence of pregnancy (Figure 1 and Table 1)..
As illustrated in Figure 1, conceived and non-conceived repeat breeder heifers exhibited progressive increases in $\mathrm{P} 4$ concentrations from 0 day to 8 days of the cycle, being lower in conceived than non-conceived heifers. The conceived animals had serum P4 concentrations of about 6 to $9.5 \mathrm{ng} / \mathrm{ml}$ during luteal phase, which were comparable to luteal concentrations reported by Foster et al. (1997) from 11-18 day of estrous cycle. The sharp reduction in $\mathrm{P} 4$ concentration in nonreturn/non-conceived heifers post-treatment may be related to failure in embryo implantation or early embryonic mortality. In this respect, Moore et al. (2005) observed lower concentrations of serum P4 coincident with embryo loss between day 24 and 28 .

The results in Table (1) illustrated that P4 concentration pre-treatment increased in nonconceived compared with conceived heifers, being in an opposite trend at service. The observed increased in P4 level of repeat breeding animals was reported and the origin of the excessive $\mathrm{P} 4$ during estrus in repeat breeder heifers is still unknown, but it could be due to either an incomplete CL luteolysis or a release from sources other than the ovary (Waldmann, 2001).

In treated repeat breeder heifers (nonconceived), marginally elevated plasma P4 level at estrus, so-called supra-basal P4 levels, has earlier been measured and is believed to impair fertility.

This P4 could be of extra-gonadal origin (Båge et al., 2000). It is possible that the suprabasal P4 concentrations present in nonconceived repeat breeder heifers during estrus reduced tubal contractility, resulting in an impaired or delayed sperm transport from the sperm reservoir to the site of fertilization (Singh et al., 2005).

Concentration of P4 post-treatment was higher in conceived than in non-conceived animals, being more than $1 \mathrm{ng} / \mathrm{ml}$. Such finding may be attributed to presence of CL, regardless conception of animals. Mee et al. (1993) mentioned that GnRH induced increase in blood P4 levels in repeat breeder cows, which might be one of the causes of the increased CR in these cows.

Concentration of $\mathrm{P} 4$ on day 24 postinsemination was $5.855 \mathrm{ng} / \mathrm{ml}$ in conceived versus less than $0.5 \mathrm{ng} / \mathrm{ml}$ in non-conceived heifers $(0.131 \mathrm{ng} / \mathrm{ml})$. Similarity, El-Moghazy (2003) mentioned that P4 concentration was almost higher than $1 \mathrm{ng} / \mathrm{ml}$ in pregnant and less than $1 \mathrm{ng} / \mathrm{ml}$ in those failed to conceive.

The present results indicated benefits of GnRH treatment at the time of insemination to synchronize the onset of estrus and ovulation 
with insemination and consequently incidence of pregnancy of most repeat breeder heifers.

\section{$2^{\text {nd }}$ Protocol: "GnRH-PGF $\alpha-G n R H^{\prime \prime}$ :}

Results in Table (2) revealed that $50 \%$ of treated heifers $(5 / 10)$ exhibited estrous activity within $48 \mathrm{hr}$ post- $\mathrm{PGF}_{2} \alpha$ injection (day 7). Conception rate ( $\mathrm{CR}$ ) was $80 \%$ (4/5) of inseminated animals. Mean diameter of the largest follicles after $\mathrm{PGF}_{2} \alpha$ injection was 8.3 and $7 \mathrm{~mm}$ in conceived and non-conceived heifers, respectively.

In comparable with the obtained results, ElMoghazy (2003) found that the percentage of cyclic buffalo cows that responded to the GnRH-PGF $2 \alpha$ injection was $48.3 \%$. However, Hegazy (2001) found that the percentage of animals responding to $1^{\text {st }} \mathrm{GnRH}$ injection was lower in cyclic animals (13\%). The variation in incidence of estrous activity in cyclic buffaloes following the $1^{\text {st }}$ GnRH-PGF $2 \alpha$ injection may be related to the luteal phase of treated animals (El-Moghazy, 2003) or incidence of silent ovulation in some animals (Hegazy, 2001).

After the $2^{\text {nd }} \mathrm{GnRH}$ (day 9) and blind insemination (day 10) as shown in Table (2), $\mathrm{CR}$ was $60 \%$ (3/5) treated/inseminated animals.

In this respect, Martel (2008) reported that the $2^{\text {nd }} \mathrm{GnRH}$ injection subsequently induced ovulation in $87 \%$ of the cows. The timing insemination applied in this study was according to the results of Sterry et al. (2007), who found that $C R$ increased when the $2^{\text {nd }}$ $\mathrm{GnRH}$ injection was $72 \mathrm{~h}$ post- $\mathrm{PGF}_{2} \alpha$ compared with $48 \mathrm{hr}$ post- $\mathrm{PGF}_{2} \alpha$ injection. Data in Table (2) revealed that mean diameter of the largest follicle after $2^{\text {nd }} \mathrm{GnRH}$ injection was larger in conceived than in non-conceived heifers (8.9 vs. $4.7 \mathrm{~mm}$ ). Perry et al. (2005) found decreased conception rates in female beef cattle induced to ovulate follicles of a smaller diameter within a CO-Synch program.

The final CR was $70 \%$ after GnRH-PGF $2 \alpha-$ GnRH protocol (7/10). Mean diameter of the largest follicles was significantly $(\mathrm{P}<0.05)$ lower in non-conceived than in conceived heifers (Table 2). Improving CR of repeat breeder heifers treated with this protocol was mainly related to that administration of $\mathrm{GnRH}$ leads to an LH surge during any stage of the estrous cycle, which will promote the ovulation of a dominant follicle or induce luteinization and/or atresia of pre-dominant follicles (Guilbault et al., 1990). Also, increasing $\mathrm{CR}$ of this protocol requires the presence of a dominant follicle at the time of the $1^{\text {st }} \mathrm{GnRH}$ injection (De Rensis et al., 2005). In buffaloes, the Ovsynch protocol has been observed to synchronize ovulation, ranging between $78 \%$ (Baruselli, 2001) and
90\% (Paul and Prakash 2005) of animals, with conception rates, averaging 60\% (Baruselli, 2001) or ranging between 33 and 50\% (Paul and Prakash, 2005). The main synchronizing effect seems to reside in the $2^{\text {nd }} \mathrm{GnRH}$ injection, whereas the importance of the $1^{\text {st }}$ $\mathrm{GnRH}$ is in prolonging the luteal phase in animals treated late in the cycle (Peters, 2005). Finally, a $2^{\text {nd }} \mathrm{GnRH}$ injection is administered 48 hours after $\mathrm{PGF}_{2} \alpha$ to induce a preovulatory LH surge that triggers ovulation within an $8 \mathrm{hr}$ period, beginning approximately $24 \mathrm{hr}$ after the injection (Pursley et al., 1995).

Induced ovulation of heifers following the GnRH-PGF $2 \alpha-G n R H$ protocol would be anticipated approximately $28 \mathrm{hr}$ after the $2^{\text {nd }}$ $\mathrm{GnRH}$ injection, whereas spontaneous ovulation of heifers exhibiting estrus would be anticipated approximately $31 \mathrm{hr}$ after the onset of estrus or approximately $19 \mathrm{hr}$ after insemination (Pursley et al., 1995). In this respect, Doležel et al. (2002) hypothesized that GnRH administration would be performed in all experimental cows by the end of the growing phase or at the beginning of the static phase of the dominant follicle when GnRH would be administered 72, 48 and $24 \mathrm{hr}$ after $\mathrm{PGF}_{2} \alpha$ in cows bearing small, medium and large follicles at the time of initial treatment.

Concentration of $\mathrm{P} 4$ pre-treatment tended to be slightly lower in conceived than nonconceived heifers. However, post $1^{\text {st }} \mathrm{GnRH}$ injection, P4 concentration increased in conceived and non-conceived heifers indicating presence of functional CL after the ovulation induced by $1^{\text {st }}$ GnRH. Post- $\mathrm{PGF}_{2} \alpha$ injection, $\mathrm{P} 4$ concentration sharply reduced to $0.433 \mathrm{ng} / \mathrm{ml}$ in conceived animals, being significantly $(\mathrm{P}<0.05)$ lower than $1.420 \mathrm{ng} / \mathrm{ml}$ in non-conceived heifers (Table 3 and Figure 2).

Such reduction may indicate a complete regression of the functional $\mathrm{CL}$ in all conceived heifers and some of non-conceived heifers. Based on serum progesterone, complete luteal regression after $\mathrm{PGF}_{2} \alpha$ and higher ovulatory responses to $\mathrm{GnRH}$ contributed to higher conception to timed artificial insemination in Ovsynch protocol (Cordoba and Fricke, 2002). Post-2 $2^{\text {nd }}$ GnRH injection, P4 concentration increased in all treated heifers, being significantly $(\mathrm{P}<0.05)$ higher in conceived than in non-conceived heifers $(5.214 v s .3 .645 \mathrm{ng} / \mathrm{ml})$.

The $2^{\text {nd }} \mathrm{GnRH}$ injection induced growing of new dominant follicle, which ovulated within $24 \mathrm{hr}$ and subsequent increased $\mathrm{P} 4$ concentrations by an average of $24 \mathrm{hr}$ relative to animals just receiving a $\mathrm{GnRH}-\mathrm{PGF}_{2} \alpha$ regimen (Peters et al., 1999). 
Results in Table (3) also indicated that P4 concentration was significantly $\quad(\mathrm{P}<0.05)$ higher in conceived than in non-conceived heifers on day 24 post-insemination (7.694 vs. $0.146 \mathrm{ng} / \mathrm{ml})$.

\section{$3^{r d} \operatorname{protocol}\left(\mathrm{PGF}_{2} \alpha-P G F_{2} \alpha\right)$ :}

Results in Table (4) show that estrus/insemination rate of heifers within 48-72 hr Post- ${ }^{\text {st }}$ PGF $_{2} \alpha$ injection was $50 \%(5 / 10)$ and $\mathrm{CR}$ was $80 \%$ (4/5). Ultrasound examination on day of $1^{\text {st }} \mathrm{PGF}_{2} \alpha$ injection showed that mean diameter of CL was 11.3 $\mathrm{mm}$.

Post- $2^{\text {nd }} \mathrm{PGF}_{2} \alpha$ injection of other nonresponded animals $(\mathrm{n}=5)$, all heifers $(100 \%)$ exhibited estrous activity within $48-72 \mathrm{hr}$ and conceived after insemination, being higher $(\mathrm{P}<0.05)$ than those post- ${ }^{\text {st }} \mathrm{PGF}_{2} \alpha$ injection. Mean diameter of CL on day of the $2^{\text {nd }} \mathrm{PGF}_{2} \alpha$ injection was $10.6 \mathrm{~mm}$, being insignificantly lower than that post- ${ }^{\text {st }} \mathrm{PGF}_{2} \alpha$ injection (Table 4). The higher response to estrus post $-2^{\text {nd }}$ $\mathrm{PGF}_{2} \alpha(100 \%)$ may indicate that at the $2^{\text {nd }}$ $\mathrm{PGF}_{2} \alpha$ injection 11 days later, the initially responsive group should be on days 7 to 9 (early cycle) of a new cycle, and the remainder would be at a broader range of a new estrous cycle (days 6 to 15), but still responsive to the luteolysin. Therefore, the majority of animals should be in early stages of the estrous cycle at the $2^{\text {nd }} \mathrm{PGF}_{2} \alpha$ injection (Hardin et al., 1980).

In this study, estrus incidence was within 48-72 hr post- $1^{\text {st }}$ or $2^{\text {nd }} \mathrm{PGF}_{2} \alpha$ and follicular diameter ranged between 10.6 and $11.6 \mathrm{~mm}$ on day of both injections (Table 4). The time interval between $\mathrm{PGF}_{2} \alpha$ treatment and the onset of estrus in buffalo varies according to the stage of estrous cycle at the time of $\mathrm{PGF}_{2} \alpha$ administration. De Rensis and Pez-Gatius (2007) observed that animals treated when follicles are in the pre-dominance stage of development display estrus 4-6 days later, whereas animals treated in the presence of a dominant follicle display estrus 2-3 days after $\mathrm{PGF}_{2} \alpha$ administration. Since the intervals between treatment, estrus, and ovulation vary after $\mathrm{PGF}_{2} \alpha$ administration, a timed artificial insemination protocol cannot be applied. The present interval from $\mathrm{PGF}_{2} \alpha$ treatment to estrus reported in this study is in line with other reports (Sahasrabudhe and Pandit 1997), while it was slightly shorter than $88 \mathrm{hr}$ (Brito et al., 2002). This interval was shorter when $\mathrm{PGF}_{2} \alpha$ is given during the early luteal phase of the estrous cycle in the presence of a dominant follicle (Baruselli, 2001).

At the end of $3^{\text {rd }}$ protocol, only one out of 10 heifers failed to conceive after $2^{\text {nd }} \mathrm{PGF}_{2} \alpha$ injection and CR was $90 \%$. In comparable the present results with other reports, Brito et al.
(2002) found that a single or double-treatment regimens of $\mathrm{PGF}_{2} \alpha$ in buffalo induced estrus and ovulation in $60-80 \%$ of animals. The obtained higher CR in this study post- $1^{\text {st }}$ or $2^{\text {nd }}$ $\mathrm{PGF}_{2} \alpha$ injections was attributed to an appropriate time of estrus incidence and consequently good time of insemination and fertilization. However, Répási et al. (2006) found that more animals became pregnant $(\mathrm{P}>0.05)$ if they were inseminated within 4 days after $\mathrm{PGF}_{2} \alpha$ treatment in dairy cows.

Concerning $\mathrm{P} 4$ profile (Table 5) the results indicated that $\mathrm{P} 4$ concentration was above 1 $\mathrm{ng} / \mathrm{ml}$ pre-treatment. This was associated with high diameter of $\mathrm{CL}$ of $\mathrm{PGF}_{2} \alpha$-treated animals.

Meanwhile, post- ${ }^{\text {st }} \mathrm{PGF}_{2} \alpha$ injection, $\mathrm{P} 4$ level markedly decreased below $1 \mathrm{ng} / \mathrm{ml}$ in animals responded to estrus (conceived and non-conceived heifers) as a result of CL regression, initiation of new follicular wave and onset of estrus. In non-responded heifers $(\mathrm{n}=5), \mathrm{P} 4$ concentration was $4.471 \mathrm{ng} / \mathrm{ml}$, indicating no incidence of estrus or silent ovulation in these animals. On day 24 postinsemination, P4 concentration was $6.2 \mathrm{ng} / \mathrm{ml}$ in responded animals, indicating incidence of pregnancy. After the $2^{\text {nd }} \mathrm{PGF}_{2} \alpha$ injection of non-responded animals to the $1^{\text {st }} \mathrm{PGF}_{2} \alpha$ injection, P4 concentration pre- and postinjection as well as on day 24 post-service showed similar trend to those conceived after the $1^{\text {st }} \mathrm{PGF}_{2} \alpha$ injection (Table 5).

In buffaloes, the effect of $\mathrm{PGF}_{2} \alpha$ administration herein is very similar to that observed in cattle. The administration of $\mathrm{PGF}_{2} \alpha$ from day 5 of the estrous cycle causes regression of CL. Thereafter, P4 declines rapidly to basal concentrations within $24 \mathrm{hr}$ resulting in induction of estrus and ovulation (Chohan et al., 1995).

\section{Reproductive and economic evaluation of different protocols:}

From the reproductive point of view, 24 out of 30 treated buffalo heifers $(80 \%)$ were conceived using all hormonal protocols, being the highest in $\mathrm{PGF}_{2} \alpha-\mathrm{PGF}_{2} \alpha(90 \%)$, moderate $(80 \%)$ in $\mathrm{GnRH}$ at insemination and the lowest $(70 \%)$ in $\mathrm{GnRH}-\mathrm{PGF}_{2} \alpha-\mathrm{GnRH}$ protocol. Also, the economic evaluation, based on cost of hormal injections, indicated that $\mathrm{PGF}_{2} \alpha-\mathrm{PGF}_{2} \alpha$ had the cheapest cost, followed by GnRH at insemination, while GnRH- $\mathrm{PGF}_{2} \alpha-\mathrm{GnRH}$ protocol showed the highest cost. Generally, using $\mathrm{PGF}_{2} \alpha-\mathrm{PGF}_{2} \alpha$ protocol showed the lowest cost $(1.8 \mathrm{~L} . \mathrm{E} /$ treated animal) with the highest conception rate (90\%, Table 6).

According to the foregoing results, using $\mathrm{PGF}_{2} \alpha-\mathrm{PGF}_{2} \alpha$ protocol as therapeutic treatment was mor efficient in improving reproductive erformance of repeat breeder 
buffalo heifers with the lowest cost as compared to other hormonal protocols $(\mathrm{GnRH}$ at service or $\mathrm{GnRH}-\mathrm{PGF}_{2} \alpha-\mathrm{GnRH}$ ) used in this study.

\section{REFERENCES}

Båge, R., 2002. On repeat breeding in dairy heifers. With special focus on follicular dynamics, ovulation and oocyte quality. $\mathrm{Ph}$. D. Thesis. Swedish University of Agricultural Sciences Uppsala .

Båge, R., M. Forsberg, H. Gustafsson, B. Larsson and H. Rodríguez-Martínez, 2000. Effect of ACTH-challenge on progesterone and cortisol levels in ovariectomised repeat breeder heifers. Anim. Reprod. Sci., 63: 6576.

Båge, R., H. Gustafsson, M. Forsberg, B. Larsson and H. Rodr'ýguez-Mart'ýnez, 1997. Suprabasal progesterone levels in repeat-breeder heifers during the pro- and estrus-period. Theriogenology, 47: 141142.

Bartlett, P.C., J.H. Kirk and E.C. Mather, 1986. Repeated insemination in Michigan Holstein-Friesian cattle: incidence, descriptive epidemiology and estimated economic impact. Theriogenology, 26: 309-322.

Baruselli, P.S., 2001. Control of follicular development applied to reproduction biotechnologies in buffalo. In: Proceedings of the I Congresso Nazionale sull'allevamento del Bufalo, Italy. Book of the Congress, 128-146.

Brito, L.F.C, R. Satrapa, E.P. Marson and J.P. Kastelic, 2002. Efficacy of PGF2alpha to synchronize estrus in water buffalo cows (Bubalus bubalis) is dependent upon plasma progesterone concentration, corpus luteum size and ovarian follicular status before treatment. Anim Reprod Sci., 73: 23-35.

Chohan, K.R., J. Iqbal, R.A. Choudhary and A.H. Khan, 1995. Oestrous response and fertility in true anestrus buffaloes following hormonal treatment during summer. Pak. Vet. J., 15:68-72.

Cordoba, M.C. and P.M. Fricke, 2002. Initiation of the breeding season in a grazing based dairy by synchronization of ovulation. J. Dairy Sci., 85:1752-1763.

De Rensis, F. and B. Pez-Gatius, 2007. Protocols for synchronizing estrus and ovulation in buffalo (Bubalus bubalis): A review. Theriogenology, 67: 209-216.

De Rensis, F., G. Ronci, P. Guarneri, B.X. Nguyen, G.A. Presicce, G. Huszenicza, 2005. Conception rate after fixed time insemination following ovsynch protocol with and without progesterone supplementation in cyclic and non-cyclic Mediterranean Italian buffaloes (Bubalus bubalis). Theriogenology, 63:1824-1831.

Doležel, R.S, J. Zajic. and V. Havlicek, 2002. Oestrus synchronization by PGF $2 \alpha$ and $\mathrm{GnRH}$ in Intervals according to stage of follicular develo.pment at time of initial treatment in cows. Acta. Vet. Brno., 71: 101-108.

El-Moghazy, M.M.M., 2003. Physiological studies on the postpartum reproductive performance in buffaloes. Ph.D. Thesis, Fac. Agric., Mansoura Univ., Egypt.

Foster, B.A., J.R. Gingrich, E.D. Kwon, C. Madias and N.M. Greenberg, 1997. Characterization of prostatic epithelial cell lines derived from transgenic adenocarcinoma of the mouse prostate (TRAMP) model. Cancer Res. 57:33253330.

Guilbault, L.A., J.G. Lussier, F. Grasso, P. Matton, 1990. Influence of a GnRH analogue on follicular dynamics in cow pretreated or not with FSH-P. Theriogenology, 33: 240-251.

Hardin, D.R., A.C. Warnick, T.H. Wise, R.H. Schultze and M.J. Fields, 1980. Artificial insemination of subtropical commercial beef cattle following synchronization with cloprostenol. Theriogenology, 14: 249258.

Hegazy, M.M.A., 2001. Physiological study on reproduction in Egyptian buffaloes (Hormonal control of ovarian activity in post-partum buffaloes). M. Sc. Thesis, Fac. Agric., Mansoura Univ., Egypt.

Kaim M., A. Bloch, D. Wolfenson, R. BrawTal, M. Rosenberg and Y. Folman, 2003. Effects of GnRH administered to cows at the onset of estrus on timing of ovulation, endocrine responses, and conception. J. Dairy Sci., 86: 2012-2021.

Martel, C.A., 2008. Fertility after timed artificial insemination response to a controlled internal drug release (CIDR) insert in lactating dairy cows. M.Sc. Thesis; Fac.of Manhattan; Kansas State University.

Mee, M.O., J.S. Stevenson, B.M. Alexander and R.G. Sasser, 1993. Administration of $\mathrm{GnRH}$ at estrus influences pregnancy rates, serum concentration of $\mathrm{LH}, \mathrm{FSH}$, estradiol$17 \beta$, pregnancy specific protein $\mathrm{B}$, and progesterone, proportion of luteal cell types, and in vitro production of progesterone in dairy cows. J. Anim. Sci., 71: 185-198.

Moore, D.A., M.W. Overton, R.C. Chebel, M.L. Truscott and R.H. BonDurant, 2005. Evaluation of factors that affect embryonic 
loss in dairy cattle. J. Am. Vet. Med. Assoc., 226: 1112-1118.

Mussard, M.L., C.R. Burke, C.L. Gasser, E.J. Behlke, K.A. Colliflower, D.E. Grum and M.L. Day, 2003. Ovulatory response, luteal function and fertility in cattle induced to ovulate dominant follicles of early or late maturity. Biol Reprod., 68: 332-333.

Nakao, T., J. Shirakawa, M. Tsurubayashi, K. Oboshi, Y. Sawamukai, N. Saga, N. Tsunoda and K. Kawata, 1984. Apreliminary report on the treatment of ovulation failure in cows with gonadotrophin-releasing hormone analog or human chorionic gonadotrophin combined with insemination. Anim. Reprod. Sci., 7: 489-495.

Nebel, R.L. and S.M. Jobst, 1998. Evaluation of systematic breeding programmes for lactating cows: A review. Journal of Dairy Science, 81: 1169-1174.

Paul, V. and B.S. Prakash, 2005. Efficacy, of the ovsynch protocol for synchronization of ovulation and fixed-time artificial insemination in Murrah buffaloes (Bubalus bubalis). Theriogenology, 64: 1049-1060.

Perry, G.A., M.F. Smith, M.C. Lucy, J.A. Green, T.E. Parks, M.D. MacNeil, A.J. Roberts and T.W. Geary, 2005. Relationship between follicle size at insemination and pregnancy success. Proc. Natl. Acad. Sci., USA, 102: 5268-5273.

Perry, G.A., M.F. Smith, A.J. Roberts, M.D. MacNeil and T.W. Geary, 2007. Relationship between size of the ovulatory follicle and pregnancy success in beef heifers, J. Anim Sci., 85:684-689.

Peters A.R., 2005. Veterinary clinical application of GnRH questions of efficacy . Animal Reproduction Science, 88 :155-167

Peters, A.R., S.J. Ward, M.J. Warren, P.J. Gordon, G.E. Mann and R. Webb, 1999. Ovarian and hormonal responses of cows to treatment with an analogue of gonadotrophin releasing hormone and PGF2 $\alpha$. Vet. Rec., 144: 343-346.

Pursley, J.R., M.O. Mee and M.C. Wiltbank, 1995. Synchronization of ovulation in dairy cattle using GnRH and PGF2 $\alpha$. Theriogenology, 44: 915-23.

Répási, A., Z. Szelenyi, G. Sassi, J. Reiczigel and O. Szenci, 2006. Effect of different prostaglandin protocols on fertility in dairy cows. Slov. Vet. Res. Ljubljana., 43: 1-338.
Rivera, H., R.A. Sterry and P.M. Fricke1, 2006 Presynchronization with gonadotropinreleasing hormone does not improve fertility in Holstein heifers. J. Dairy Sci., 89: 3810-3816.

Ryan, D.P., S. Snijders, T. Condon, M. Grealy, J. Sreenan and K.J. O'Farrell, 1994. Endocrine and ovarian responses and pregnancy rates in dairy cows following the administration of a gonadotrophin releasing hormone analog at the time of artificial insemination or at mid-cycle postinsemination. Anim. Reprod. Sci., 34: 179-191.

Sahasrabudhe, S.A. and R.K. Pandit, 1997. PGF2a induced oestrus in suboestrus Murrah buffaloes during summer. Indian J. Anim. Sci., 67: 513- 514.

Singh, B., F. Saravia, R. Båge, H. RodríguezMartínez, 2005. Pregnancy rates in repeat breeder heifers following multiple artificial inseminations during spontaneous oestrus. Acta Vet. Scand, 46: 1-12.

Snedecor, G., Statistical Methods. $7^{\text {th }}$ Ed. Iowa Univ. Press, Ames. Iowa, USA.

Sterry, R.A., P.W. Jardon and P.M. Fricke, 2007 Effect of timing of CoSynch on fertility of lactating Holstein cows after first postpartum and Resynch timed-AI services. Theriogenology, 67, 1211-1216.

Stevenson, J.S., K.D. Frantz and E.P. Call, 1988. Conception rates in repeat-breeders and dairy cattle with unobserved estrus after prostaglandin F2 alpha and gonadotropin- releasing hormone. Theriogenology, 29: 451-460.

Stevenson, J.S., M.K. Schmidt, and E.P. Call, 1984. Gonadotropin-releasing hormone and conception in Holsteins. Journal of Dairy Science, 67: 140-145.

Waldmann, A., O. Reksen, K. Landsverk, E. Kommisrud, E. Dahl, A.O. Refsdal, 2001. Progesterone concentrations in milk fat at first insemination - effects on non-return and repeat-breeding. Anim. Reprod. Sci., 65(1): 33-41.

Yaniz, J.L., K. Lopez, and F. Gatiusf, 2004. Recent developments in oestrous synchronization of postpartum dairy cows with and without ovarian disorders. Reprod. Domest. Anim., 39(2): 86-93. 
Table 1. Profile of P4 $(\mathrm{Mean} \pm \mathrm{SE})$ in blood serum of conceived and non-conceived heifers treated with GnRH at insemination during treatment

\begin{tabular}{lcc}
\hline \multicolumn{1}{c}{ P4 concentration $(\mathbf{n g} / \mathbf{m l})$ : } & Conceived $(\mathbf{n}=\mathbf{8})$ & Non-conceived $(\mathbf{n}=\mathbf{2})$ \\
\hline Pre-treatment & $3.063 \pm 0.97$ & $5.828 \pm 1.12$ \\
At estrus & $0.182 \pm 0.03$ & $0.596 \pm 0.04$ \\
Post-treatment & $5.802 \pm 0.54$ & $3.541 \pm 0.81$ \\
24 days post-insemination & $5.855 \pm 0.25$ & $0.131 \pm 0.04$ \\
\hline
\end{tabular}

Table 2. Conception rate, estrus rate and diameter of largest follicle of conceived and nonconceived heifers in the $2^{\text {nd }}$ protocol.

Post-GnRH + PGF $2 \alpha$ injections:

Number of treated animals

Estrus/insemination rate, $\%$

Conception rate, \% (based on inseminated animals)

$80(4 / 5)$

Diameter of largest follicle of conceived heifers, $\mathrm{mm}$

$8.3 \pm 1.52$

Diameter of largest follicle of non-conceived heifers, $\mathrm{mm}$

$7.0 \pm 0.00$

Post-2 ${ }^{\text {nd }}$ GnRH injection (timing insemination):

Number of treated animals

Estrus/insemination rate

CR (\%) (based on timing insemination)

$60(3 / 5)$

Diameter of largest follicle of conceived heifers, $\mathrm{mm}$

$8.9 \pm 1.41$

Diameter of largest follicle of non-conceived heifers, $\mathrm{mm}$

$4.7 \pm 0.80$

The whole protocol:

Number of treated animals

Total CR (\%)

$70(7 / 10)$

Diameter of largest follicle of conceived heifers, $\mathrm{mm}$

Diameter of largest follicle of non-conceived heifers, $\mathrm{mm}$

$\mathrm{a}$ and $\mathrm{b}$ : Means denoted within the same column with different superscripts are significantly different at $\mathrm{P}<0.05$.

Table 3. Progesterone profile (ng/ml) pre-, during and post- GnRH- PGF 2 -GnRH treatment.

\begin{tabular}{lcccc}
\hline \multicolumn{1}{c}{ Sampling time } & \multicolumn{3}{c}{ Conceived } & Non- conceived \\
\cline { 2 - 5 } & $\mathbf{n}$ & $\mathbf{P 4}(\mathbf{n g} / \mathbf{m l})$ & $\mathbf{n}$ & $\mathbf{P 4}(\mathbf{n g} / \mathbf{m l})$ \\
\hline Pre-treatment & 7 & $3.014 \pm 0.25$ & 3 & $3.588 \pm 0.41$ \\
Post $1^{\text {st }} \mathrm{GnRH}_{\text {injection }}$ & 7 & $4.682 \pm 0.74$ & 3 & $5.209 \pm 0.54$ \\
Post- $\mathrm{PGF}_{2} \alpha$ injection & 7 & $0.433 \pm 0.021^{\mathrm{b}}$ & 3 & $1.420 \pm 0.032^{\mathrm{a}}$ \\
Post $2^{\text {nd }} \mathrm{GnRH}_{\text {injection }}$ & 3 & $5.214 \pm 0.82^{\mathrm{a}}$ & 2 & $3.645 \pm 0.76^{\mathrm{b}}$ \\
24 days post-service & 7 & $7.694 \pm 1.02^{\mathrm{a}}$ & 3 & $0.146 \pm 0.042^{\mathrm{b}}$ \\
\hline Means denoted within the same row with different superscripts are significantly different at $\mathrm{P}<0.05$. NS: Not \\
significant. ${ }^{\mathrm{b}}$ Significant at $\mathrm{P}<0.05$.
\end{tabular}

Table 4. Conception rate, estrus rate and follicular diameter of heifers treated with $\mathrm{PGF}_{2} \alpha$ $\mathrm{PGF}_{2} \alpha$ protocol

\section{Pre-treatment:}

Number of treated animals

Diameter of corpus luteum, mm

Post- $1^{\text {st }}$ PGF $_{2} \alpha$ :

Estrus/insemination rate, $\%$

Conception rate, $\%$ (inseminated based on heat)

Pre-2 ${ }^{\text {nd }}$ PGF $_{2} \alpha$ :

Number of treated animals

Diameter of corpus luteum, mm

Post- $2^{\text {nd }}$ PGF $_{2} \alpha$ :

Estrus/insemination rate, $\%$

Conception rate, $\%$ (inseminated based on heat)

$50(5 / 10)^{\mathrm{b}}$

$80(4 / 5)^{\mathrm{B}}$

Total protocol:

Number of treated animals

Diameter of corpus luteum, mm

$100(5 / 5)^{\mathrm{a}}$

$100(5 / 5)^{\mathrm{A}}$

Estrus/insemination rate, $\%$

Conception rate, $\%$

Means denoted within the same column with different superscripts are significantly different at $\mathrm{P}<0.05$. 
Table 5. Progesterone $\left(\right.$ Mean \pm SE) profile $(\mathrm{ng} / \mathrm{ml})$ pre-, during and post-PGF $2 \alpha-\mathrm{PGF}_{2} \alpha$ treatment

\begin{tabular}{|c|c|c|c|c|c|c|}
\hline \multirow{3}{*}{ Item } & \multicolumn{4}{|c|}{ Responded animals } & \multirow{2}{*}{\multicolumn{2}{|c|}{ Non-responded* }} \\
\hline & \multicolumn{2}{|r|}{ Conceived } & \multicolumn{2}{|c|}{ non-conceive } & & \\
\hline & $\mathbf{N}$ & P4 (ng/ml) & $\mathbf{N}$ & P4 (ng/ml) & $\mathbf{n}$ & P4 (ng/ml) \\
\hline Pre-treatment & 4 & $4.469 \pm 0.257$ & 1 & $3.928 \pm 0.0$ & 5 & $3.143 \pm 0.584$ \\
\hline \multicolumn{7}{|l|}{$1^{\text {st }}$ PGF $_{2} \alpha$ injection: } \\
\hline Post- injection** & 4 & $0.081 \pm 0.011$ & 1 & $0.798 \pm 0.0$ & 5 & $4.471 \pm 0.425$ \\
\hline Day 24 post-service & 4 & $6.203 \pm 0.542$ & 1 & $0.313 \pm 0.0$ & & - \\
\hline \multicolumn{7}{|l|}{$2^{\text {nd }}$ PGF $_{2} \alpha$ injection: } \\
\hline Pre injection & 5 & $4.471 \pm 0.425$ & - & - & - & - \\
\hline Post injection** & 5 & $0.291 \pm 0.005$ & - & - & - & - \\
\hline Day 24 post-service & 5 & $7.619 \pm 1.02$ & - & - & - & - \\
\hline
\end{tabular}

Table 6. Reproductive evaluation and economic efficiency of different hormonal treatments

\begin{tabular}{|c|c|c|c|c|}
\hline \multirow{2}{*}{ Item } & \multicolumn{3}{|c|}{ Hormonal protocol } & \multirow{2}{*}{ Total } \\
\hline & GnRH $^{(1)}$ & G-P-G $\mathbf{G}^{(2)}$ & $\mathbf{P}-\mathbf{P}^{(3)}$ & \\
\hline \multicolumn{5}{|c|}{ Reproductive evaluation of treatment: } \\
\hline Treated animals (n) & 10 & 10 & 10 & 30 \\
\hline Conceived animals (n) & 8 & 7 & 9 & 24 \\
\hline Non conceived $(n)$ & 2 & 3 & 1 & 6 \\
\hline Conception rate $(\%)$ & 80 & 70 & 90 & 80 \\
\hline \multicolumn{5}{|c|}{ Economic efficiency of treatment: } \\
\hline Treatment period (day) & 0 & 10 & 11 & - \\
\hline Price of $1^{\mathrm{st}}$ injection (L.E.) & 200 & 200 & 120 & 520 \\
\hline Price of $2^{\text {nd }}$ injection (L.E.) & - & 120 & 60 & 180 \\
\hline Price of $3^{\text {rd }}$ injection (L.E.) & - & 100 & - & 100 \\
\hline Total cost (L.E./group) & 200 & 420 & 180 & 800 \\
\hline
\end{tabular}

${ }^{(1)}$ : GnRH at service ${ }^{(2)}:$ GnRH-PGF $2 \alpha-\mathrm{GnRH}{ }^{(3)}: \mathrm{PGF}_{2} \alpha-\mathrm{PGF}_{2} \alpha$

Price of each injection from GnRH and $\mathrm{PGF}_{2} \alpha$ was 20 and 12 L.E, respectively.

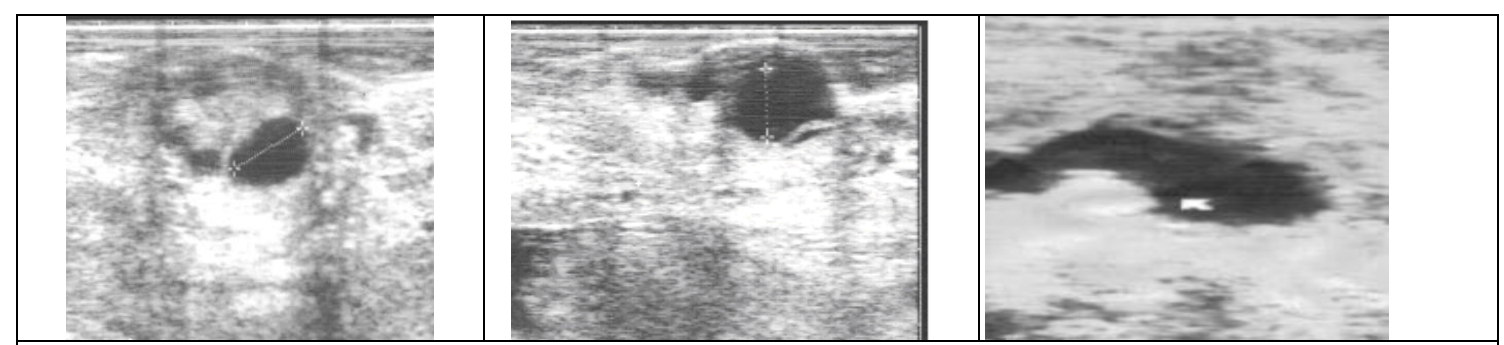

Plate (1): Ultrasonography examination of heifer treated with GnRH at insemination showing: ovarian follicle with $10.04 \mathrm{~mm}$ in diameter in conceived animal (A) and ovarian follicle with 9.00 $\mathrm{mm}$ in dianfter in non-conceived apimal (B) at insemination ac Cwell as embry on day 35 postinsemination, indicating the incidence of pregnancy.

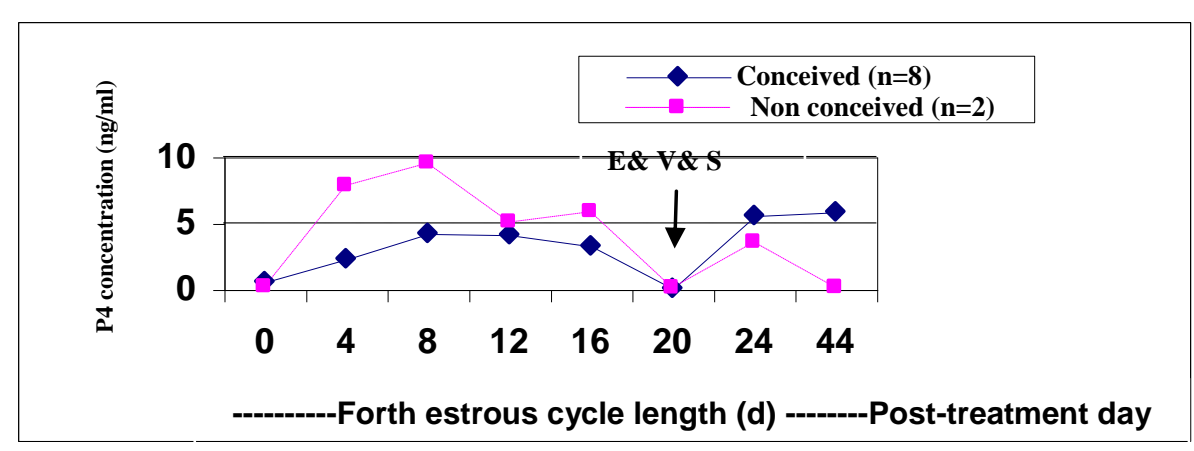

Fig. 1. Progesterone profile during the fourth estrous cycle (pre-treatment) and post- GnRH treatment in conceived and non-conceived heifers. (E: estrus, V: ovulation and S: service) 


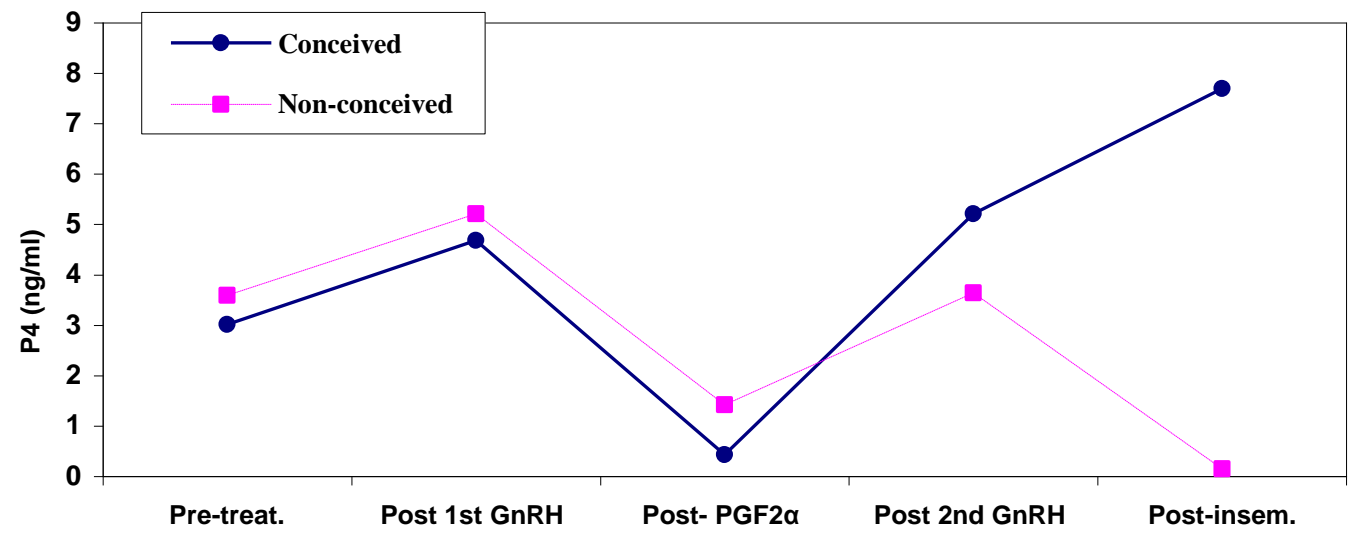

Fig. 2. Progesterone profile pre-, during and post- GnRH-PGF ${ }_{2} \alpha-G n R H$ treatment.

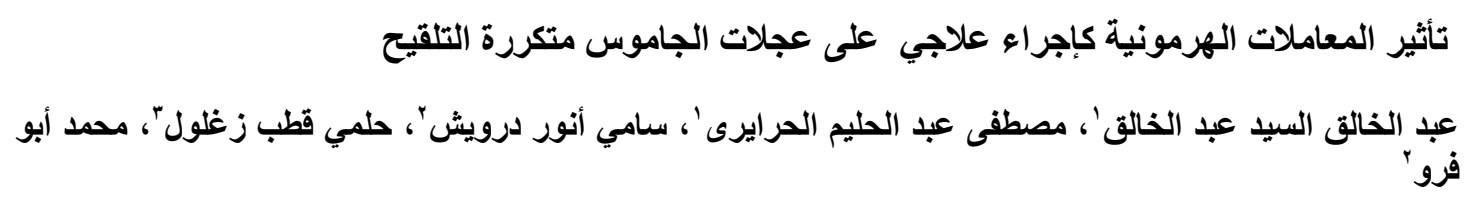

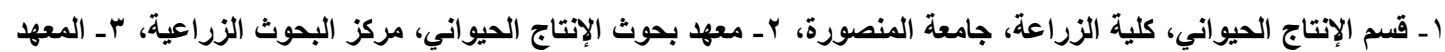

العالي للتعاون الزراعي بشبرا الخيمة، القاهرة

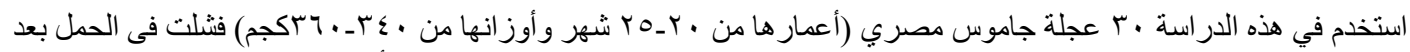

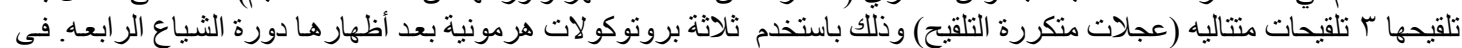

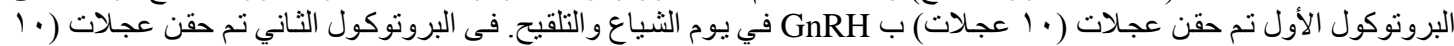

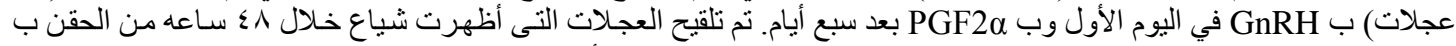

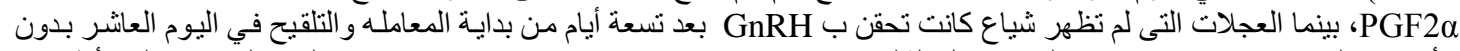

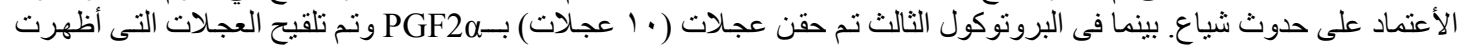

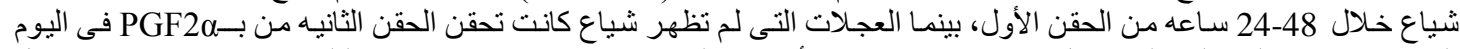

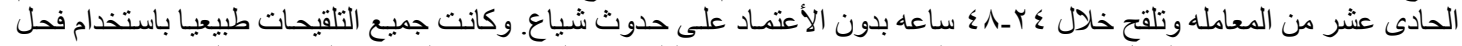

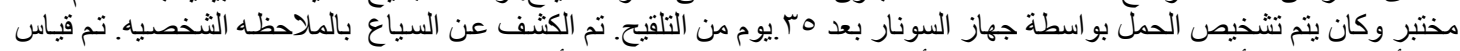

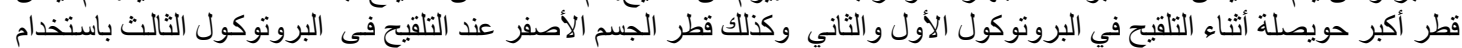

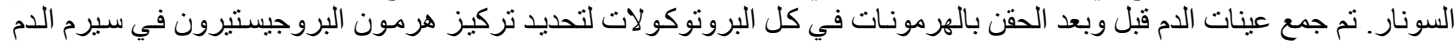

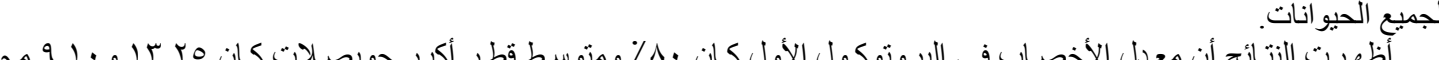

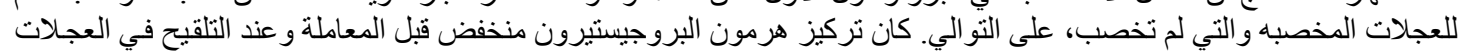

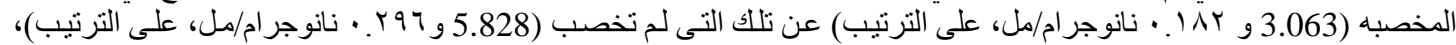

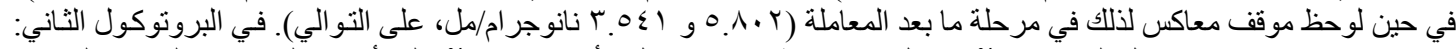

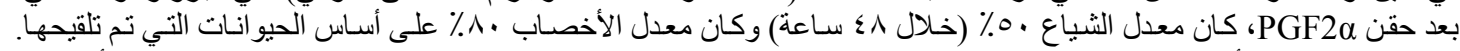

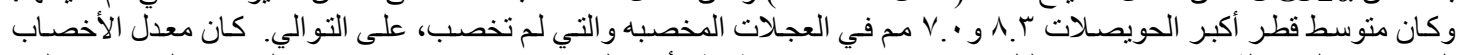

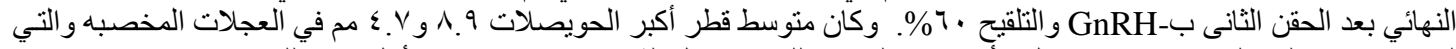

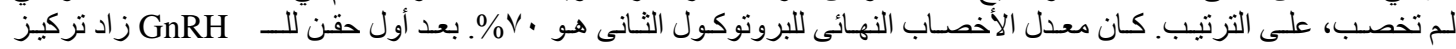

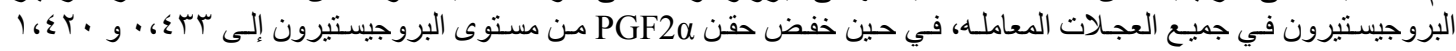

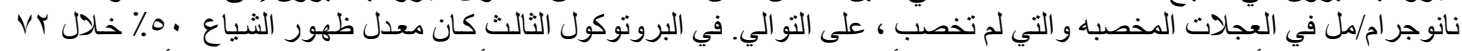

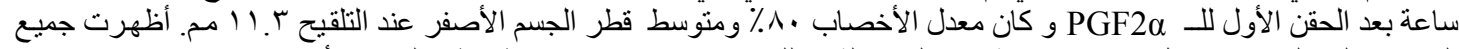

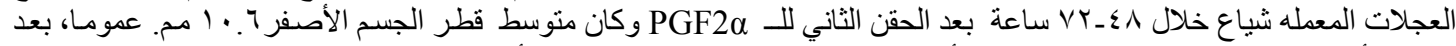

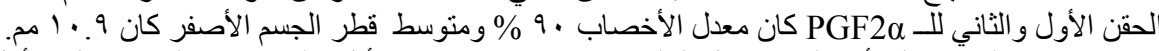

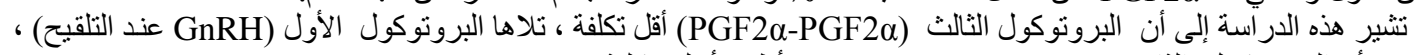

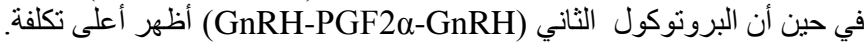

